\title{
ZALOŻENIA GEOPOLITYKI IWANA IV GROŹNEGO I JEJ REALIZACJA W ROSJI W LATACH 1547-1584. CZ. I
}

\begin{abstract}
W artykule przestawiono główne założenia geopolityczne w czasach rządów cara Rosji Iwana IV Groźnego i sposoby ich realizacji. Ekspansję Rosji w tym czasie ukierunkowała w dużym stopniu geografia, ale za konkretne działania w czasie i przestrzeni odpowiadał Iwan IV. Jeszcze w okresie Wielkiego Księstwa Moskiewskiego wytyczono główne zamierzenia geostrategiczne. Należały do nich: 1. Zapewnienie bezpieczeństwa od strony granic wschodnich państwa i skierowanie ekspansji przeciwko państwom będących spadkobiercami Mongołów. 2. Zdobycie dostępu do Bałtyku i przesunięcie granic na zachód w celu zjednoczenia ziem należących na przestrzeni wieków do Rusi Kijowskiej. To „zbieranie ziem ruskich” miało też połączyć wyznawców prawosławia pod jednym panowaniem Cerkwi rosyjskiej. 3. Rozbudowa odpowiedniej ideologii dla uzasadnienia spraw politycznych. W tym czasie pojawia się teoria przedstawiająca Moskwę jako „Trzecie Rzym”, mająca po upadku Konstantynopola potwierdzać władzę Moskwy nad wszystkimi ludami prawosławnymi, a w przyszłości także będąca czynnikiem uzasadniającym roszczenia rosyjskie do terenów po byłym Cesarstwie Bizantyńskim. Iwan IV Groźny w wyniku podjętych działań stał się jednym z pierwszych władców rosyjskich, który z dużymi sukcesami realizował te założenia geopolityczne, odnosząc przy tym również porażki. Był też pierwszym władcą, który dzięki swoim działaniom stworzył pojęcie „eurazjatyckiej Rosji”. Artykuł składa się z części omawiających realizację planów Iwana IV Groźnego oraz jego sukcesy i porażki na trzech głównych kierunkach jego polityki. Cele, jakie sobie wyznaczył car, nie zostały przez niego w pełni zrealizowane, ale odgrywały rolę uniwersalną także dla przyszłych władców Rosji, którzy jakby wypełniając jego testament polityczny, dążyli do podobnych celów w polityce zagranicznej. Osąd działań cara Iwana IV w Rosji dziś nie jest jednoznaczny, oceny wahają się od uwielbienia aż po nienawiść.

Słowa kluczowe: Iwan IV Groźny, geopolityka, Rosja w XVI wieku, wojny rosyjskie.
\end{abstract}

\section{WPROWADZENIE}

Europa Wschodnia do Uralu, jako granicy kontynentu, z geopolitycznego punktu widzenia długo nie odgrywała praktycznie żadnej roli. Przez cały okres starożytności i wczesnego średniowiecza nie wykształciły się na tym ogromnym i słabo zaludnionym terenie państwa przypominające charakterem despotyczne monarchie (Asyria, Chiny, Persja), wpływowe miasta-państwa (jak w Helladzie) czy imperia - cesarstwa na miarę Rzymu, Bizancjum czy państwa Franków. Mimo to X w. przyniósł ze sobą ważne zmiany na mapie Europy w jej wschodniej części. Plemiona słowiańskie w wyniku rozwoju

${ }^{1}$ Mgr Krzysztof Surowiec, asystent w Zakładzie Nauk Humanistycznych, Wydział Zarządzania, Politechnika Rzeszowska, autor korespondencyjny: e-mail: ks@prz.edu.pl

${ }^{2}$ Prof. dr hab. Aleksander Razin, kierownik Katedry Etyki Moskiewskiego Państwowego Uniwersytetu im. M. Łomonosowa. 
społecznego i gospodarczego doprowadziły do wykształcenia się grup współdziałania ze sprawującymi władzę książętami plemiennymi, co zapoczątkowało zmiany ustrojowe i geopolityczne w tej części Europy. Powstały nowe państwa: Polska, Ruś Kijowska, Czechy oraz inne. Nastąpiła również zmiana ustroju demokracji wojennej na bardziej scentralizowane formy monarchii. Raz powstałe państwa, mimo wzlotów i upadków, na stałe wkomponowały się w układ sił, tworząc jednolitą Europę mimo różnic politycznych, religijnych (szczególnie od czasów schizmy wschodniej z 1054 r.) czy kulturalnych. Największym i najsilniejszym państwem, które wyłoniło się na przestrzeni wieków na terenie Europy Wschodniej, była Rosja jako następczyni Wielkiego Księstwa Moskiewskiego. Sukces tego państwa mozolnie budowanego przez kilkaset lat opierał się na podejmowaniu dobrych decyzji geopolitycznych, zwykłym szczęściu, którego również państwa doświadczają, jak i wytrwałym dążeniu do postawionych celów. Jednym z pierwszych władców, który z podrzędnego państwa europejskiego za wielką cenę zbudował silne terytorialnie państwo, był Iwan IV Groźny z dynastii Rurykowiczów. Na bazie tej mogli budować potęgę państwa car Aleksy Michajłowicz, Piotr Wielki oraz Katarzyna II Wielka. W końcu średniowiecza sukces Moskwy wcale nie był pewny i przewidywalny, konkurentów do zjednoczenia ziem ruskich oraz wrogów zewnętrznych nie brakowało. Ukształtowanie się Rosji Iwana IV czy Piotra Wielkiego poprzedzone było całą serią strategicznych wyborów dokonywanych przez władców Rusi, które ukształtowały ten kraj do dziś.

Problem badawczy niniejszego artykułu jest następujący: wjakim stopniu realizacja wyborów geopolitycznych przez Iwana IV Groźnego przyczyniła się do stworzenia podstaw imperium rosyjskiego ${ }^{3}$ w późniejszych wiekach? Natomiast celem jest przedstawienie doniosłości realizacji kierunków polityki wewnętrznej, jak i zewnętrznej tego cara wraz z jego sukcesami i porażkami. Przedmiotem badań zostały objęte rządy Iwana Groźnego w latach 1533-1584 w różnych aspektach geopolitycznych. Główna hipoteza badawcza streszcza się w stwierdzeniu, że rządy Iwana Groźnego doprowadziły do budowy podstaw rosyjskiej mocarstwowości i imperializmu, czemu były podporządkowane działania tego władcy zarówno na arenie międzynarodowej, jak i wewnętrznej Rosji ${ }^{4}$.

\section{SYTUACJA ZIEM ROSYJSKICH W DOBIE WYBORÓW GEOSTRATEGICZNYCH PÓŹNEGO ŚREDNIOWIECZA}

Wieki XV i XVI w całej Europie - od Portugalii po Moskwę - były okresem wielkiego rozwoju. Przeobrażenia społeczne, gospodarcze i kulturalne docierały również do wschodniej Europy. Powoli zaczęła się tworzyć gospodarka światowa, gdzie rola późniejszej Rosji jako łącznika z państwami Azji Środkowej i Wschodniej miała wielkie znaczenie. Budowa scentralizowanej monarchii carów rezydujących w Moskwie zaczęła

\footnotetext{
${ }^{3}$ P.Y.Wipper, Ivan Grozny, Moskwa 1994, s. 16.

${ }^{4}$ Iwan IV Groźny i jego rządydoczekały sięwieleopracowań:A. Pawłow, M.Perrie, Iwan Groźny. Car i tyran, Warszawa 2008;J. Martin, MedievalRussi, 980-1584, Cambridge 1995;S.F. Płatonow, Ivan the Terrible, GulfBreeze 1974; R.G.Skrynnikow, Ivan the Terrible, GulfBreeze 1981; I. de Madriaga, Ivan the Terrible, New Haven 2005; A.Andrusiewicz, Iwan Groźny, Warszawa 2006;B. Floria, Iwan Groznyj, Moskwa 1999; W.Kobrin, Iwan Groznyj, Moskwa 1989;W.A. Serczyk, Iwan Groźny, Wrocław-Warszawa-Kraków-Gdańsk 1977; Z.Wójcik, Wokót epoki Iwana Groźnego, „Kwartalnik Historyczny” 1975/2 .
} 
się dość późno ${ }^{5}$, wzmiankowano ją po raz pierwszy w 1147 r. Początkowo nie odgrywała większej roli wśród starszych i silniejszych państw tego regionu, takich jak: Nowogród Wielki, Riazań, Suzdal czy Włodzimierz. Mimo ekspansji Księstwa, a później Wielkiego Księstwa Moskiewskiego jego rozwój gospodarczy oraz cywilizacyjny był zakłócany nie tylko przez państewka ruskie, ale również przez innych etnicznych wrogów, takich jak Szwedzi, niemieccy rycerze zakonni znad Bałtyku, Litwa, a później również Polska czy wreszcie Mongołowie ${ }^{6}$. Oni to zadali największą klęskę młodemu państwu moskiewskiemu, doprowadzając do długoletniej stagnacji ziem ruskich, co zakończyło się dopiero w wyniku bitwy pod Kulikowym Polem 8 września 1380 r. Od tego momentu Moskwa niezagrożona przez Mongołów przystąpiła do szerokiej ekspansji, mając silne poparcie podporządkowanej państwu Cerkwi prawosławnej. Zwierzchnictwo religijne Moskwy datowane jest na rok 1326, kiedy została przeniesiona do niej siedziba metropolity z Włodzimierza. Pozbycie się kurateli mongolskiej spowodowało - jak twierdzi Hélène Carrèred'Encausse- zapoczątkowanie narodzin narodu rosyjskiego ${ }^{7}$. Powoli już w XIV i XV w. przestrzeń geograficzna zaczęła odgrywać dużą rolę dziejach przyszłej Rosji, była również imperatywem działania kolejnych władców, wymuszając określone działania $^{8}$. Położenie ziem rosyjskich na styku Europy i Azji, tworzące tzw. Eurazję, czyli terytorium dominacji Imperium Rosyjskiego, powoli stawało się pojęciem nie tylko geograficznym, ale również historyczno-religijno-kulturalnym ${ }^{9}$. Rosja stawała się coraz bardziej osobnym światem położonym na styku dwóch kontynentów, według samych Rosjan idealnym, tworzącym nawet „ósmy kontynent" ${ }^{\text {"10 }}$. Przez wieki to właśnie swego rodzaju izolacjonizm i ekskluzywizm państwa rosyjskiego w oczach ideologów i historyków prowadził do budowania własnej drogi rozwoju. Wielką rolę w tym odgrywał Iwan Groźny, którego wpływ na mentalność rosyjską widoczny był na przykład w XX w. w wypowiedziach i działaniach Stalina ${ }^{11}$.

${ }^{5}$ Zob. szerzejS. Franklin,J. Sheppard, The Emergence of Rus, 750-1200, London 1996.

${ }^{6} \mathrm{O}$ mongolskichwpływachnaRusipatrz:Ch.J. Halperin, Russia and Golden Horde: the Mongol Impact on Medieval Russian History, London 1987; D.Ostrowski, Muscovyand the Mongols: Cross-Cultural Influences on the Steppe Frontier, 1304-1589, Cambridge 1998.

${ }^{7}$ H.Carrèred'Encausse, Eurazjatyckie imperium. Historia Imperium Rosyjskiego od 1552 r. do dzisiaj, Kęty 2014, s. 29-30. W wyniku zręcznej polityki po Kulikowym Polu pozycja Moskwy wśród księstw ruskich została uznana i nie była już kwestionowana.

${ }^{8} \mathrm{O}$ znaczeniu przestrzeni w dziejach Rosji i jej geopolityce zob. szerzej:I. Salimow, PoliticzieskajageomorfologijaRossiji, [w:] Impierijaprostranstwa. Chriestomatija po gieopolitikie i gieokulturieRossiji, red. D.N.Zamiatin,A.N. Zamiatin, Moskwa 2003, s. 17 i n.; P.Gołąbek, Lew Gumilow i Aleksander Dugin. O dwóch obliczach eurazjatyzmu w Rosji po 1991 roku, Kraków 2012, s. 47-59.

${ }^{9}$ Por. W.A. Michajłow, Gieopolitika. Ucziebnik, Moskwa 2010;K. Chojnicka, Idee towarzyszace procesowi uzyskiwania przez Moskwe dominacji na ziemiach ruskich w XV, XVI wieku, [w:] Oblicza Wschodu w kulturze polskiej,red. G. Kotlarski, M. Figura, Poznań 1999.

${ }^{10}$ Określenie to znalazło się w tytule książki:W. Zajączkowski, Rosja i narody. Ósmy kontynent. Szkic dziejów Eurazji,Warszawa 2009, s. 3-6, 33-89; następuje tu charakterystyka Rosji jako imperium przestrzennego, które autor nazwał „ósmym kontynentem”, specyficznym, różnorodnym religijnie i etnicznie. Na temateurazjatyzmu por. równieżR. Paradowski, Eurazjatyckie imperium Rosji. Studium Idei, Toruń 2001.

${ }^{11}$ Por.D. Madejski, Pocatunek mongolskiego księcia. Eurazjatyzm Rosji w myśli Aleksandra Dugina cz. I, 2011, http://www.konserwatyzm.pl/artykul/3266/pocalunek-mongolskiego-ksieciaeurazjatyzm-rosji-w-mysli-ale(dostęp: 15.01.2016). 
„Geopolityczne orientacje”12 - określenie użyte przez Andrzeja Nowaka- na długo wyznaczały sukcesy i porażki państwa rosyjskiego, poczynając od XV i XVI w. Stworzyły również Rosję Stalina, Chruszczowa, Breżniewa i ich następców. Wybory takich orientacji można zauważyć od 988 r., kiedy to Włodzimierz Wielki przyjął chrzest z ośrodka bizantyjskiego, w którym później powstało prawosławie, tak mocno oddziałujące na ducha Rosji przez całe wieki. Nad decyzją tą wspomniany władca zastanawiał się długo, a możliwości wyboru było więcej: nie tylko zachodnia, łacińska wizja, ale również $w$ grę wchodził judaizm wyznawany przez Chazarów czy islam przyjęty przez Bułgarów kamskich (sąsiadów Rusi) z bardzo rozwiniętego ośrodka państwa Abbasydów. Jak wyglądałby dzisiejszy świat, gdyby decyzja Włodzimierza była inna? Już decyzja o przyjęciu chrztu, a później wielka schizma wschodnia skutecznie oddzieliły Rosję od Zachodu. Prawosławie stało się czynnikiem budującym tożsamość religijną, kulturową oraz geopolityczną Rosjan. Założenie patriarchatu moskiewskiego w 1589 r. za czasów cara Fiodora, o co zabiegał usilnie również jego ojciec -Iwan IV Groźny, bardzo wzmocniło siłę oddziaływania Rosji na państwa, gdzie mieszkali przedstawiciele prawosławia. Miękka siła (softpower) oddziaływania religijnego Cerkwi rosyjskiej połączona $\mathrm{z}$ twardą siłą państwa rosyjskiego przyczyniły się do włączenia terytoriów Ukrainy (1648 r. i rozbiory Polski), Białorusi (rozbiory Polski), Kaukazu czy stworzenia strefy wpływów od XVIII w. na terenie Bałkanów (Serbia, Rumunia, Bułgaria czy Grecja) ${ }^{13}$.

Dzieje Wielkiego Księstwa Moskiewskiego i powstanie Rosji tworzyły trzy

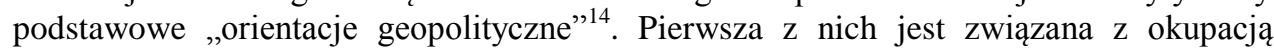
mongolską i jej upadkiem ostatecznie w 1480 r. Głównym architektem tego sukcesu był Iwan III Srogi. Złota Orda, jako spadkobierczyni państwa Czyngis-chana na Zachodzie, przeżywała w tym czasie swój upadek i nie mogła się przeciwstawić sukcesom Moskwy. Rozpad Złotej Ordy zapoczątkował przejmowanie przez Moskwę dziedzictwa po Mongołach. Ta decyzja doprowadziła do ekspansji Moskwy na wschód Azji, aż do Pacyfiku. Miało to ogromne znaczenie, ponieważ z Azji Środkowej coraz bardziej były rugowane imperia stepowe, łączące tzw. magistralą stepową ${ }^{15}$ świat Azji Wschodniej z

\footnotetext{
${ }^{12}$ A.Nowak, Putin. Źródła imperialnej agresji, Warszawa 2014, s. 16.

${ }^{13}$ Pojęcie ,softpower" - miękka siła- zostało stworzone przez Josepha Nye'a.Autor definiuje je następująco: ,jest to zdolność uzyskiwania tego, czego się chce, raczej dzięki atrakcyjności niż przymusowi czy pieniądzom. Jest ona rezultatem atrakcyjności, kultury, politycznych ideałów i konkretnej polityki danego kraju. Jest ona formą siły danego państwa, a nie wynikiem jego słabości”. Zob. szerzej:J. Nye, Soft Power. Jak osiagnać sukces w polityce światowej, Warszawa 2007, s. 10 i n.

${ }^{14}$ Odnośnie do historycznych koncepcji geopolitycznych w Rosji zob. szerzej:W. Aleksiejewa,J.I. Zieleniew, W.I.Jakunin, Gieopolitika w Rossiji. MieżduWostokom i Zapadom. Koniec XVIII naczało XX w., Sankt-Petersburg 2001;J.P. LeDonne, The Russian Empire and the World. The Geopolitics of Expansion and Containment, Oxford 1997.

${ }^{15}$ Pojęcie użyte przez:J. Morris, Dlaczego Zachód rządzi - na razie, Poznań 2015, s. 328-330, 538-543. Terytorium mało urodzajnych równin od Mongolii do Węgier, gdzie w I tys. lat p.n.e. doszło do wykształcenia się nowego modelu życia: koczownictwa, jeżdżących na koniach pasterzy. Konsekwencje dla koczowników zamieszkujących magistralę stepową były bardzo doniosłe: ich swoboda przemieszczenia została przerwana, a oni sami zostali zepchnięci do roli najemników, jak na przykład Kozacy. Natomiast dwa imperia, Rosja i Chiny, zyskały nowe pogranicza, gdzie mogli osiedlać się mieszkańcy z ośrodków bardziej przeludnionych. To
} 
Chinami na czele (wraz z jej kulturą i wynalazkami) z Europą Zachodnią. Zamknięcie magistrali stepowej w XVIII w. przez Rosję i Chiny, wyznaczyło Rosji rolę pośrednika między Europą a Azją oraz ostatecznie zlikwidowało zagrożenie płynące z działalności niespokojnych imperiów stepowych.

Jednak do roli państwa silnego i znaczącego w Europie XV i XVI w. droga wiodła Rosję na Zachód. Narodziła się wtedy ideologia „zbierania ziem ruskich”. Ta orientacja geopolityczna nawiązywała do terenów zajmowanych przez Ruś Kijowską w okresie największego jej rozwoju, a nawet $\mathrm{w}$ trakcie podziałów dzielnicowych tego państwa. Tutaj Moskwa, a później Rosja miała silniejszego przeciwnika niż Mongołowie, mianowicie Litwę, a od 1569 r. całą Rzeczpospolitą. Państwo rosyjskie szczególnie interesowałosię dostępem do Bałtyku, a później do Morza Czarnego. Zrealizowanie tego projektu ostatecznie udało się Piotrowi Wielkiemu, choć i Iwan Groźny miał na tym polu kilka sukcesów.

Trzecim czynnikiem, który odgrywał ogromną rolę w poczynaniach władców Rosji na przestrzeni wieków, była idea imperium ${ }^{16}$ światowego, „trzeciego Rzymu”"17. Ta idea geopolityczna uznawała Moskwę jako uniwersalnego obrońcę prawosławia na świeciew spadku po Bizancjum ${ }^{18}$. Moskwa miała być ostatnim, wielkim, uniwersalnym imperium w dziejach świata po Rzymie i Bizancjum. Upadek Konstantynopola w 1453 r. doprowadził do jej sformułowania przez pskowskiego mnicha Filoteusza ${ }^{19}$. Podbudowaniem tej ideologii było małżeństwo wielkiego księcia moskiewskiego Iwana III Srogiego z przedstawicielką dynastii rządzącej Bizancjum ZoePaleolog ${ }^{20}$. Zaślubiny dokonały się w 1472 r., a Zofia wniosła dla władcy Moskwy wiele korzyści: Iwan III jako godło ustanowił dwugłowego orła bizantyńskiego, a także tu miały źródło pretensje władców Moskwy, a później Rosji do władzy na Konstantynopolem i terenami byłego Cesarstwa Bizantyńskiego. Tutaj w kierunku południowo-wschodnim głównym

zamknięcie magistrali stepowej zdaniem Morrisa przyczyniło się do rewolucyjnego rozwoju społecznego w XVIII w.

16 Pojęcie „imperium” w kontekście Rosji jest od dawna dyskutowane w nauce. Zdaniem badacza zachodniego Emila Paina: „Imperium to państwo poddanych, opierające się na przymusie i podporządkowaniu, gdy tymczasem naród - państwo to państwo obywateli, zjednoczonych wzajemnymi interesami i samoorganizacją". Główną cechą imperium zdaniem Paina jest ustrój oparty na autorytarnej władzy. Por. W.Marciniak, Imperium i państwo: historia pojęć w kontekście dziejów Rosji, [w:] Rosja i Europa Wschodnia: ,,imperiologia stosowana”,red.A. Nowak, Kraków 2006, s. 46-59;E.A. Pain, Mieżduimperiej a nacyiej. Modernistskij projekt $i$ jgotradicyonalistkajaaltiernativa $w$ nacyonalnojpolitikieRossii,FondLibieralnajamisija, Moskwa 2003.

${ }^{17}$ Por.N.I. Chodakowski, TretijRim, Moskwa 2002.

18 Najstarszym zachowanym dokumentem, w którym została zaprezentowana teoria trzech Rzymów, jest list Filoteusza do księcia Wasyla III Rurykowicza z 1510 r. Por. J.H. Billington,Ikona i topór. Historia kultury rosyjskiej, Kraków 2008, s. 53-54. W 1492 r. również metropolita Moskwy, Zosima Brodaty, używa teorii Moskwy - jako trzeciego Rzymu, por.B.Uspienski, Religia i semiotyka, wybrał, przeł. i przedmową opatrzył B.Żyłko, Gdańsk 2001, s. 41 in.

${ }^{19}$ Podkreśla się, że Filoteusz nie zamierzał tworzyć ideologicznej podbudowy rosyjskiej polityki zagranicznej, a jedynie dążył do wzmocnienia roli prawosławia i podkreślenia, że jest to jedyna słuszna wiara. Por. N.V.Riasanovsky, M.D. Steinberg,Historia Rosji, Kraków 2009, s. 129.

${ }^{20}$ K.Chojnicka, Narodziny rosyjskiej doktryny państwowej. ZoePaleolog - między Bizancjum, Rzymem a Moskwa, Kraków 2001. 
przeciwnikiem dla Rosji stała się Porta Osmańska, z którą wojny były toczone przez długie wieki, a ich usprawiedliwieniem była walka $\mathrm{z}$ niewiernymi oraz solidaryzm $\mathrm{z}$ ludnością prawosławną, zamieszkującą Bałkany. Polityka wobec prawosławia na terenach innych państw europejskich miała charakter ponadregionalny, uniwersalistyczny ${ }^{21}$.

Zdaniem Paula Kennedy'ego Rosja w XIV-XVI w. przypominała swoim położeniem geopolitycznym Japonię $\mathrm{w}$ wiekach XVII-XIX ${ }^{22}$. Wiązało się to $\mathrm{z}$ pewnym oddalaniem od Zachodu (zła komunikacja, brak dostępu do Bałtyku i Morza Czarnego w wyniku kordonu państw: Szwecji, Litwy, Polski, Porty Otomańskiej), mimo to Rosja pozostawała pod wpływem dziedzictwa europejskiego, również pod względem wyposażenia armii: działa i muszkiety rozwiązały problem zagrożenia ze strony koczowników i chanatów azjatyckich i umożliwiły ekspansję na Syberię, aż do wybrzeży Pacyfiku (plany te zostały osiągnięte w 1638 r.). Trudniejszą ekspansję Rosjanie mieli w kierunku zachodnim ${ }^{23}$.

\section{POCZATKI RZACÓW IWANA IV GROŹNEGO: KORONACJA NA} CARA, PODBÓJ POWOLŻA

Można powiedzieć, że geografia oraz splot okoliczności, nierzadko szczęśliwych, była głównym czynnikiem sprawczym, wymuszającym określone działania Iwana IV Groźnego na polu polityki zagranicznej. Władca ten urodził się w 1530 r. i po okresie regencji osobiste rządy zaczął sprawować od 1547 r. Jako pierwszy władca rosyjski przyjął tytuł cara. Rozpoczynając rządy, Iwan IV objął władzę nad byłym Wielkim Księstwem Moskiewskim, którego terytorium rozrosło się bardzo za panowania jego poprzedników: Iwana III Srogiego i Wasyla III (Jarosław dołączony w 1463 r., Rostów w 1474 r., Nowogród Wielki w 1478 r., Twer w 1485 r., Psków w 1510 r., Smoleńsk w 1514 r., Riazań w 1521 r. oraz tereny wschodniej Litwy) ${ }^{24}$. Mając tak duże państwo, Iwan IV mógł przystąpić do realizacji szerokiej ekspansji, która stworzyła w przyszłości podwaliny pod imperium rosyjskie. Okres małoletniości Iwana IV bardzo ukształtował

${ }^{21}$ Zob. szerzej M. Poe, Izobrietienijekoncepciji „,Moskwa - trietij Rim”, „Ab Imperio” 2000/2, s. 61-86; D. Rowland, Moscow - The Third Rome or the New Israel?, „Russian Review” 1996. Jak twierdzi Feliks Koneczny, projekt ślubu Iwana III z Zoe mógł wypłynąć od despotów Mangupu na Krymie - Kommenów, por. F.Koneczny, Cywilizacja bizantyńska, Londyn 1973, s. 289. Zob. szerzej K.Bojko, Stosunki dyplomatyczne Moskwy z Europa Zachodnia w czasach Iwana III, Kraków 2010, s. 45-54.

${ }^{22}$ P.Kennedy, Mocarstwa świata. Narodziny, rozkwit, upadek, Warszawa 1994, s. 30-31.

${ }^{23}$ Według Michaiła Hellera Rosja w XVI w. liczyła około 8-10 mln ludności.M. Heller, Historia Imperium Rosyjskiego, Warszawa 2009, s. 146.

24 Według Lwa Gumilowa to polityka prowadzona szczególnie przez Iwana III Srogiego doprowadziła do powstania nowego rosyjskiego etnosu - „,naturalnie ukształtowana na podstawie oryginalnego stereotypu zachowań społeczność istniejąca jako system, który przeciwstawia siebie innym podobnym systemom na zasadzie poczucia komplementarności", który zastąpił dawny etnos związany z Rusią. W XVI w. za panowania Wasyla III, Iwana IV Groźnego i Fiodora rosyjski superetnos nieustannie się rozszerzał, oznaczał on, według Gumilowa, ,system etniczny składający się z kilku etnosów powstałych w jednym regionie klimatycznym i w jednakowych warunkach naturalnych, który występuje w dziejach jako mozaikowa całość". Inaczej mówiąc,superetnos to grupa etnosów w jednym regionie, na przykładsuperetnos Bizancjum złożony był Greków, Egipcjan, Ormian, Słowian, Syryjczyków. W superetnosie rosyjskim zaczęły się również tworzyć subetnosy, czyli podsystemy, takie jak Kozacy dońscy. Poglądy Gumilowa są uważane za kontrowersyjne przez naukowców, choćnie można im odmówić oryginalności. Zob. szerzejL. Gumilow, Od Rusi do Rosji, Warszawa 2004, s. 8-15, 174-202. 
jego charakter, a spory i walki frakcyjne kolejnych koterii możnowładców, sprawujących regencję nad małoletnim władcą wyzwoliły w nim nieufność, przekonanie o własnej racji, a także przeświadczenie, że tylko siła decyduje o skuteczności rządów. Pierwszy rosyjski car przez cały okres swoich rządów działał zgodnie z zasadą „divide et impera”, a kto z tym się nie zgadzał, musiał ponieść ciężkie konsekwencje, niezależnie od piastowanych godności i pochodzenia społecznego.

Iwan IV już po kilku latach rządów i pierwszych reformach w duchu centralizmu zaczął realizować politykę zagraniczną w kierunku wyznaczonym przez geopolitykę. Mając silniejszych przeciwników na Zachodzie, zaczął od państw leżących za wschodnimi granicami Rosji. Złota Orda rozpadła się, z tego podziału powstały nowe państwa koczownicze na peryferiach imperiów, mianowicie: Chanat Kazański w 1438 r., Chanat Krymski w 1441 r., Chanat Astrachański w tym samym roku oraz dalej Orda Nogajska i Chanat Syberyjski. Zadanie zdobycia tych terenów było o tyle ułatwione, że w państwach tych dochodziło do nieustannych walk wewnętrznych, a pozostałe mocarstwa nie były zainteresowane tymi ziemiami. Wyjątkiem tylko była Turcja, wspierająca Chanat Krymski, który w XVI w. znajdował się poza zasięgiem Rosji (ostatecznie Rosja miała go podbić dopiero w XVIII w. za czasów Katarzyny Wielkiej). Rosja w wojnach z chanatami posiadała przewagę $\mathrm{w}$ postaci artylerii i pierwszych muszkietów ${ }^{25}$. Mimo dwóch nieudanych kampanii z 1547 i 1549 r. trzecia z roku 1551 przyniosła sukcesy, co zostało uwieńczone zdobyciem Kazania w październiku 1552 r. W następnych latach włączono pozostałe ziemie chanatu do Rosji, zabezpieczono teren umocnionymi punktami, rozpoczęto misje prawosławne wśród tamtejszej ludności oraz przeprowadzono reformy w duchu centralizmu i podporządkowania carowi tych terenów, włącznie $\mathrm{z}$ władzą religijną Cerkwi ${ }^{26}$.

Wraz z przyłączeniem Kazania w historii Rosji dobiegł końca długi okres zagrożenia ze strony Mongołów lub ich następców ${ }^{27}$. Osiągnięcie Wołgi oznaczało, że to Rosja stała się państwem dominującym na tym terenie, a tereny położone na wschód od Moskwy z Niżnym Nowogrodem na czele, miały być od tej pory bezpieczne od wrogów

\footnotetext{
${ }^{25}$ Podobną przewagę, jeśli chodzi o artylerię,miała Turcja osmańska w pierwszych wiekach swojej ekspansji w Azji zachodniej przeciwko Persji Safawidów, dzięki temu bez problemu pokonała ten kraj w bitwie pod Czałdarynem w 1514 r. Zob. szerzej:S. Shaw, Historia Imperium Osmańskiego $i$ Republiki Tureckiej,t. 1: 1280-1808, Warszawa 2012, s. 142-145.

${ }^{26}$ Zaraz po zdobyciu Kazania wybudowano tam okazałą katedrę prawosławną, powstawały również cerkwie i monastery. W 1555 r. Kazań został podniesiony do rangi eparchii. Rządy Iwana IV na terenach kazańskich okazały się bardzo tolerancyjne, zabroniono nawracać przymusowo muzułmanów.Późniejsi carowie zmienili w tej kwestii zapatrywania, dochodziło do coraz większych prześladowań wyznawców islamu, szczególnie za czasów Fiodora, syna Iwana IV, który nakazał zniszczenie wszystkich meczetów na terenie dawnego Kazania. Dopiero Katarzyna Wielka przywróciła na tych terenach tolerancję, skutki przymusowego nawracania po śmierci Iwana IV nie były zbyt szczęśliwe dla Rosji w przyszłości, zob. szerzejJ. Pelenski, Russia and Kazan. Conquest and Imperial Ideology (1438-1560s), The Hague 1974, s. 251-275;M. Khodarkovsky, Four Degrees of Separation: Constructing Non-Christian Identities in Muscovy, [w:] Culture an Identity in Muscovy, 1359-1584, red. A.M. Kleimola, G.D. Lenhoff, Moskwa 1994, s. 257-264.

27 Sukcesy wobec państw położonych na Powołżu możliwe były dzięki nowej broni Rosjan, mianowicie artylerii. Według opinii posła angielskiego Gilla Fletchera: „żadne z chrześcijańskich władców tej epoki nie miał tak potężnej artylerii”. Por.M. Heller, op. cit., s. 151.
} 
zewnętrznych i szybko się rozwijać ${ }^{28}$. Z tych terenów także rozpocznie się ekspansja Rosji w niedługim czasie na Syberię. Nowe nabytki poddane zostały szybkiej rusyfikacji, można wręcz mówić o nastaniu w Rosji środkowej swego rodzaju paxrussica na linii Wołgi. Duże sukcesy w utwierdzeniu zdobyczy Iwana IV na tym terenie miał gubernator wojskowy Kazania Aleksander Gorbatyj. Iwan IV poprzestał na tym, rezydując w Moskwie, chciał wiedzieć o wszystkim, co dzieje się na Wschodzie. W wyniku tego powołał w 1553 r. tzw. dwór kazański, który później stał się prikazem, czyli ministerstwem zajmującym się sprawami byłego chanatu. O znaczeniu tego prikazu i jego wysokim statusie świadczy przynależność do tzw. wielkich prikazów, których było tylko cztery. Dużym wyzwaniem, z którym sobie dość szybko poradzono, było zasiedlenie nowych terenów kolonistami rosyjskimi. Chłopi nawet $\mathrm{z}$ zachodnich obszarów Rosji, chcąc polepszyć swoje położenie, zaczęli uzyskiwać działki nad Wołgą. Podobnie czyniła również szlachta. Iwan IV nie przeszkadzał temu, przeciwnie - wspierał przedsięwzięcie, z którym łączył wielkie nadzieje na przyszłość.

Ustanowienie za czasów Iwana IV paxrussicana wschodzie Rosji bardzo szybko przyniosło ze sobą korzyści ekonomiczne i dyplomatyczne. Przed kupcami rosyjskimi otworzyły się drogi do Persji, Indii i Chin ${ }^{29}$. Szybko tę drogę odkryła również Anglia, która zaproponowała Iwanowi IV prawa do tranzytu. Geopolityka carska znowu zatriumfowała, monopol na przedostanie się na Wschód, który dzierżyły Turcja osmańska oraz Portugalia, zmuszał Anglię do poszukiwania innych dróg dotarcia tych bogatych państw $^{30}$. Rosja $\mathrm{z}$ mało znaczącego kraju szybko stała się partnerem pożądanym $\mathrm{w}$ Londynie, z którym można było robić korzystne interesy dla obu stron. Dla ułatwienia kontaktów z Anglią w 1583 r. został założony Archangielsk, choć port ten zamarzał i nie mógł być wykorzystywany przez cały rok ${ }^{31}$.

\footnotetext{
${ }^{28}$ Nie jest dziełem przypadku, że to właśnie z terenów na wschód od Moskwy wyszła irredenta przeciwko interwencji Rzeczypospolitej w okresie Smuty po 1609 r. Tamtejsza bogata szlachta bojarska i mieszczaństwo, widząc zagrożenie dla swoich interesów i posiadając duże środki, potrafili skutecznie przywrócić spokój w Rosji.

${ }^{29}$ Handel Rosji z terenami Powołża był już wcześniej rozwinięty. Na wyprawę na Kazań Orda Nogajska przysłała do Moskwy ponad 50 tys. koni. Na szczęście dla Iwana IV Nogajcy uważali go za potomka Czyngis-chana, czego sam Iwan Groźny nie negował. Przez Ordę Nogajską przechodził też szlak handlowy z Persji do Rosji. Por. Heller M., op. cit., s. 152.

${ }^{30}$ Anglicy w drugiej połowie XVI w. podjęli próbę stworzenia drogi przez Rosję i Morze Kaspijskie do Persji oraz Indii. Utworzona w tym celu w 1555 r. Kompania Moskiewska (Muscovy Company) miała za zadanie ominięcie do krajów Wschodu geograficznego monopolu Turcji na handel lewantyński oraz portugalskiego monopolu wzdłuż wybrzeży Afryki i Indii. Względy polityczne i znalezienie innej drogi przez Anglię spowodowały załamanie się projektu handlu ze Wschodem przez Wołgę. Zob. szerzej:A.J.Gerson,E.V. Vaughn, Studies in the history of English commerce in the Tudor period. I: The organization and early history of the Muscovy company, II:English trading expeditions into Asia under the authority of the Muscovy company (1557-1581), New York 1912; T.S.Willan, The Early History of the Russia Company, 1553-1603, Manchester 1956.

${ }^{31}$ Różnorodność rozwoju gospodarczego ziem rosyjskich w XVI w. była duża. Można mówić o inwestowaniu szlachty w folwarki pańszczyźniane, co wiązało się z kontaktami zagranicznymi. Rozrastał się rynek wewnętrzny,bojarzy szukali nowych możliwości wzbogacenia się w skutek spadku swoich dochodów w połowie XVI w. Skutkiem tego było pogarszanie się sytuacji chłopów i coraz częstsze przywiązywanie ich do ziemi. Postępowała jednak kolonizacja, rozwijały się miasta i kupiectwo, hodowla oraz szczególnie gospodarka leśna. Por.J. Topolski, Narodziny
} 
Podbój Kazania rozwiązał jeden problem, ale stworzył nowy - przesuwając granice na wschód, Rosja zaczęła graniczyć i walczyć z kolejnym państwem peryferyjnym w stosunku do Rosji, Turcji i Persji, a mianowicie z Astrachaniem. Chanat ten dzierżył władztwo nad ujściem Wołgi do Morza Kaspijskiego i z tego powodu jego podbicie umożliwiłoby nowe możliwości w handlu z Persją i Wielkimi Mogołami w Indiach. Astrachań wspierał również Krym, co również brał pod uwagę Iwan IV. Iwan IV odniósł zwycięstwo, przyłączając Astrachań do swojego państwa w 1554 r. Początkowo pozwolono zachować pozory niezależności byłego chanatu w ramach Rosji. Ostatecznie niezależność Astrachania została zlikwidowana w 1556 r. Szybko przy ujściu Wołgi zaprowadzono porządki podobne do tychw Kazaniu ${ }^{32}$. Próba odzyskania zdobyczy Iwana IV poczyniona w 1569 r. przez Krym i Turcję sułtana Selima II nie powiodła się. Pozycja zdobyta nad Wołgą nie została już nigdy zachwiana, dawała ona wolny dostęp do Syberii i jej zasobów. Iwan IV nie tylko zapewnił bezpieczeństwo i stabliną pozycję na tym terenie swojego państwa, ale również stworzył pojęcie „eurazjatyckiej Rosji”.

\section{LITERATURA}

[1] Acton E., Rosja dziedzictwo caratu i władzy radzieckiej, Warszawa 2013.

[2] Aleksiejewa W., Zieleniew J.I., Jakunin W.I., Gieopolitika w Rossiji. MieżduWostokom i Zapadom. Koniec XVIII - naczało XX w., Sankt-Petersburg 2001.

[3] Andrusiewicz A., Iwan Groźny, Warszawa 2006.

[4] Bäcker R., Międzywojenny eurazjatyzm. Od intelektualnej kontrakulturacji do totalitaryzmu?, Łódź 2000.

[5] Bazylow L., Wieczorkiewicz P., Historia Rosji, Wrocław 2005.

[6] Besancon A., Święta Ruś, Warszawa 2012.

[7] Billington J. H.,Ikonaitopór. Historia kultury rosyjskiej, Kraków 2008.

[8] Bogucka M., Zboże rosyjskie na rynku amsterdamskim $w$ pierwszej połowie XVII wieku, „Przegląd Historyczny” 1962/4.

[9] Bojko K., Stosunki dyplomatyczne Moskwy z Europa Zachodnia w czasach Iwana III, Kraków 2010.

[10] Braudel F., Kultura materialna, gospodarka i kapitalizm XV-XVIII wieku. Gry wymiany,t.III, Warszawa 1992.

kapitalizmu w Europie w XIV-XVII w., Poznań 2003, s. 131-133. W wielu regionach było to spowodowane kontaktami z krajami morskimi Zachodu. Mowa tutaj o Anglii i Holandii. Maria Bogucka wskazuje początki kontaktów rosyjsko-holenderskich na ostatnie ćwierćwiecze XVI w. Zob. szerzej:M. Bogucka, Zboże rosyjskie na rynku amsterdamskim w pierwszej połowie XVII wieku, „Przegląd Historyczny”1962/4. Otwarcie przez Iwana IV portu w Narwie dla żeglugi bałtyckiej w latach 1564-1581 przyniosło bardzo duże korzyści dla handlu rosyjskiego. Jak wskazuje Fernand Braudel, już w tym czasie środek ciężkości rosyjskiej gospodarki powoli przesuwał się na północ, choć południowy wschód zachowuje swoją najważniejszą pozycję. Zob. szerzejF. Braudel, Morze Śródziemne i świat śródziemnomorski w epoce Filipa II, t. 1, Warszawa 2004, s. 204-209.

32 Wojskowym gubernatorem (wojewodą) został Czeremyszynow. Fernand Braudel porównuje znaczenie Kazania dla Rosji do znaczenia królestwa Grenady dla jednoczącej się Hiszpanii. Również w tym wypadku rozpoczęła się szybka kolonizacja nowych terenów Powołża. Por.F. Braudel, Morze Śródziemne i świat..., s. 120. 
[11] Braudel F., Morze Śródziemne i świat śródziemnomorski w epoce Filipa II,t. 1, Warszawa 2004.

[12] Carrèred'Encausse H., Eurazjatyckie imperium. Historia Imperium Rosyjskiego od 1552 r. do dzisiaj, Kęty 2014.

[13] Chodakowski N.I., TretijRim, Moskwa 2002.

[14] Chojnicka K., Idee towarzyszące procesowi uzyskiwania przez Moskwe dominacji na ziemiach ruskich w XV, XVI wieku, [w:] Oblicza Wschodu w kulturze polskiej,red. G. Kotlarski, M. Figura,Poznań 1999.

[15] Chojnicka K., Narodziny rosyjskiej doktryny państwowej. ZoePaleolog między Bizancjum, Rzymem a Moskwa, Kraków 2001.

[16] Czy Putin jest awatarem? - rozmowa z Aleksandrem Duginem, „Fronda” 2001/23-24.

[17] Fennell J.L.I., The Correspondence between Prince A. M. Kurbsky and Tsar Ivan IV of Russia, Cambridge 1955.

[18] Floria B.N., Magnateria litewska a Rosja w czasie drugiego bezkrólewia, „Odrodzenie i reformacja” 1977/XXII.

[19]Floria B.N., Russko-polskijeotnoszenii $i$ politiczeskojerazwitjeWostocznojJewropywowtoroj połowinie XVI - naczale XVII w., Moskwa 1978.

[20] Floria B.N., IwanGroznyj, Moskwa 1999.

[21] Franklin S., Sheppard J., The Emergence of Rus, 750-1200, London 1996.

[22] Gerson A.J., Vaughn E.V., Studies in the history of English commerce in the Tudor period,I:The organization and early history of the Muscovy company,II: English trading expeditions into Asia under the authority of the Muscovy company (1557-1581), New York 1912.

[23] Gołąbek P., Lew GumilowiAleksanderDugin. O dwóch obliczach eurazjatyzmu w Rosji po 1991 roku, Kraków 2012.

[24] Gumilow L., Od Rusi do Rosji, Warszawa 2004.

[25] HalperinCh.J., Russia and Golden Horde: the Mongol Impact on Medieval Russian History,London 1987.

[26]Heizer P., Neoopricznina - Aleksander Dugin i Eurazjatycki Zwiąek Młodzieży, „Przegląd Rusycystyczny”140/4 (2012).

[27] Heller M., Historia Imperium Rosyjskiego, Warszawa 2009.

[28] Historia dyplomacji polskiej, t. I: polowa X w. - 1572, red. M.Biskup, Warszawa 1982.

[29] Kaługin W., Car Iwan Groznyj i kniaź Andriej Kurbskij: Stili myszlenija i tworczestwa, [w:] Pisarz i władza. Od Awwakuma do Sotzenicyna, red. B. Mucha,Łódź 1994

[30] Kennedy P., Mocarstwa świata. Narodziny, rozkwit, upadek, Warszawa 1994.

[31] Khodarkovsky M., Four Degrees of Separation: Constructing Non-Christian Identities in Muscovy, [w:] Culture an Identity in Muscovy, 1359-1584, red.A.M. Kleimola, G.D. Lenhoff, Moskwa 1994.

[32] Khodarkovsky M., Na granicach Rosji. Budowanie imperium na stepie 1500-1800, Warszawa 2009.

[33] Kłoczowski J., Młodsza Europa, Warszawa 2003.

[34] Kobrin W., Iwan Groznyj, Moskwa 1989.

[35] Koneczny F., Cywilizacja bizantyńska, Londyn 1973. 
[36] Krasowski K., Lesiński B., Sikorska-Dzięgielewska K., Walachowicz J., Powszechna historia państwa i prawa, Poznań 1993.

[37]LeDonne J.P., The Russian Empire and the World. The Geopolitics of Expansion and Containment, Oxford 1997.

[38] Łapiński Z., Pośmiertny żywot Iwana Groźnego, „Tygodnik Powszechny” $1987 / 42$.

[39] Madejski D., Pocałunek mongolskiego księcia. Eurazjatyzm Rosji w myśli Aleksandra Dugina cz. I, 2011, http://www.konserwatyzm.pl/artykul/3266/pocalunek-mongolskiego-ksieciaeurazjatyzm-rosji-w-mysli-ale.

[40] Madriaga I. de, Ivan the Terrible, New Haven 2005.

[41] Malleson G. B., The Decisive Battles of India from 1746 to 1819, London 1885.

[42] Małowist M., Wschód a Zachód Europy XIII-XVI wieku, Warszawa 2006.

[43] Marciniak W., Imperium i państwo: historia pojęć w kontekście dziejów Rosji, [w:] Rosja i Europa Wschodnia: ,imperiologia stosowana”,red. A. Nowak, Kraków 2006.

[44] Martin J., Medieval Russi, 980-1584, Cambridge 1995.

[45] Massaka I., Eurazjatyzm. Z dziejów rosyjskiego misjonizmu, Wrocław 2001.

[46] Michajłow W.A., Gieopolitika. Ucziebnik, Moskwa 2010.

[47] Morris J., Dlaczego Zachód rządzi - na razie, Poznań 2015.

[48] Natanson-Leski J., Granica moskiewska w epoce jagiellońskiej, Oświęcim 2014.

[49] Nowak A., Putin. Źródła imperialnej agresji, Warszawa 2014.

[50]Nye J., Soft Power. Jak osiagnać sukces w polityce światowej, Warszawa 2007.

[51] Ostrowski D., Muscovy and the Mongols: Cross-Cultural Influences on the Steppe Frontier, 1304-1589, Cambridge 1998.

[52]Pain E.A., Mieżduimperiej a nacyiej. Modernistskij projekt $i$ jgotradicyonalistkajaaltiernativa $w \quad$ nacyonalnojpolitikieRossii. FondLibieralnajamisija, Moskwa 2003.

[53] Paradowski R., Eurazjatyckie imperium Rosji. Studium Idei, Toruń 2001.

[54] Pawłow A., Perrie M., Iwan Groźny. Car i tyran, Warszawa 2008.

[55] Pelenski J., Russia and Kazan. Conquest and Imperial Ideology (1438-1560s), The Hague 1974.

[56] Pipes R., Rosja carów, Warszawa 2012.

[57] Płatonow S.F., Ivan the Terrible, Gulf Breeze 1974.

[58] Poe M., Izobrietienije koncepciji „Moskwa - trietij Rim”,Ab Imperio” 2000/2.

[59] Riasanovsky N. V., Steinberg M. D.,Historia Rosji. Kraków 2009.

[60] Rojek P., Przekleństwo imperium. Źródła rosyjskiego zachowania, Kraków 2014.

[61] Rowland D., Moscow - The Third Rome or the New Israel?, „Russian Review" 1996.

[62] Salimow I., PoliticzieskajageomorfologijaRossiji, [w:] Impierijaprostranstwa. Chriestomatija po gieopolitikie $i$ gieokulturieRossiji, red.D.N. Zamiatin, A.N.Zamiatin, Moskwa 2003. 
[63] Serczyk W.A., Iwan Groźny, Wrocław-Warszawa-Kraków-Gdańsk 1977.

[64] Serczyk W.A., Radziecka dyskusja o absolutyzmie w Rosji, „Kwartalnik Historyczny" 1973/3.

[65] Shaw S., Historia Imperium Osmańskiego $i$ Republiki Tureckiej,t. 1:1280-1808, Warszawa 2012.

[66] Skrynnikow R.G., Ivan the Terrible, Gulf Breeze 1981.

[67] Skrynnikow R.G., TragiedijaNowgoroda, Moskwa 1994.

[68] Soloviev A.V., Holy Russia. The History of a Religious - Social Idea, Gravenhage 1959.

[69] Stevens C.B., Rosyjskie wojny 1460-1730. Narodziny mocarstwa, Warszawa 2003.

[70] Szczaniecki M., Powszechna historia państwa i prawa, Warszawa 2003.

[71] Tarczyński A., Podbój imperiów Inków i Azteków, Warszawa 2009.

[72] Topolski J., Narodziny kapitalizmu w Europie w XIV-XVII w., Poznań 2003.

[73] Urban W., Nowożytni najemnicy, Warszawa 2008

[74] Uspienski B., Car i patriarcha. Charyzmat władzy w Rosji. Bizantyjski model $i$ jego nowe rosyjskie ujęcie, Katowice 1999.

[75] Uspienski B., Religia $i$ semiotyka, wybrał, przeł.i przedmową opatrzył B. Żyłko, Gdańsk 2001.

[76] Willan T.S., The Early History of the Russia Company, 1553-1603, Manchester 1956.

[77] Wipper P.Y., Ivan Grozny, Moskwa 1994.

[78] Wójcik Z., Dzieje Rosji1533-1801, Warszawa 1971.

[79] Wójcik Z., Wokół epoki Iwana Groźnego, „Kwartalnik Historyczny” 1975/2.

[80]Zajączkowski W., Rosja i narody. Ósmy kontynent. Szkic dziejów Eurazji, Warszawa 2009.

[81]Zakrzewski W., Stosunki Stolicy Apostolskiej z Iwanem Groźnym i wielkim księciem moskiewskim, „Przegląd Polski” 1872-1873,t. I-IV.

\section{THE ASSUMPTIONS OF GEOPOLITICS AND ITS IMPLEMENTATION}

IN RUSSIA IVAN IV THE TERRIBLE IN THE YEARS 1547-1584. PART I

The article presents the main assumptions of the geopolitical reign of the Russian Tsar Ivan IV the Terrible and methods of their implementation. The expansion of Russia at that time has focused largely on the same geography, but to translate this into concrete actions in time and space belonged to Ivan IV. Even during the Great Duchy of Moscow the major geo-strategic ambitions were marked. These included: 1. Ensuring safety from the eastern borders of the state and directing the expansion against states that are the heirs of the Mongols. 2. Gaining access to the Baltic Sea and borders moved west, to unite the lands belonging to the centuries to Kievan Rus. This "gathering of the Russian lands" had also connect Orthodox believers under one rule of the Russian Orthodox Church. 3. Development of appropriate ideologies to justify policy issues. At this time, there is the theory of Moscow as the "Third Rome", designed after the fall of Constantinople confirmed Moscow's authority over all Orthodox peoples, and in the future being a factor justifying claims to Russian territories of the former Byzantine Empire. Ivan IV the Terrible as a result of actions taken to become one of the first rulers of Russia, who with considerable success realized these geopolitical assumptions, while also referring successes. He was also the first ruler, who created by his actions the concept of "Eurasian Russia". The article consists of two parts discussing implementation and successes and failures of Ivan IV the Terrible at the three main lines of its policy. Goals it has set itself the Tsar have not been fully realized 
by him, but he played the role of a universal for future rulers of Russia, who liked realizing his political testament aspired to similar objectives in foreign policy. The judgment of the activities of Tsar Ivan IV of Russia to this day it is not clear, from adoration to the hatred.

Keywords: Ivan IV the Terrible, geopolitics, Russia in the sixteenth century, The Russian Wars.

DOI:10.7862/rz.2016.hss.10

Przesłano do redakcji: wrzesień 2015

Przyjęto do druku: styczeń 2016 